\begin{tabular}{|c|c|c|}
\hline 森 田 竹 & 男 & 桐生機械（株） \\
\hline 山 & 義 & " \\
\hline 沢 & $=$ & 争松羊毛龍野工場 \\
\hline 嘉 & 也 & 中央毛織津工場 \\
\hline 畑 & 雄 & 大日本紡岐阜工場 \\
\hline 片 & 平 & 大阪機峨製作長岡工場 \\
\hline 野 比 & 慈 & " I \\
\hline 田辺小一 & 郎 & " \\
\hline 山 川 & 功 & " \\
\hline 井 萁 & 二 & " \\
\hline 栄 & 介 & 富士紡小山工場 \\
\hline 里 博 & 明 & 東京農工大織維学部 \\
\hline 沢田腾 太 & 郎 & 大野䋊布（株） \\
\hline 小 山 & 清 & (株) 早州製作所 \\
\hline 木 & 茂 & 東邦レーヨン德島工場 \\
\hline 野 定 & 男 & 千化田美術織物（株） \\
\hline 川 & 堅 & 清光産業（株） \\
\hline 林 & 卓 & 東洋紡本社 \\
\hline 正 & 臣 & " \\
\hline 野 義 & 雄 & 富土紡本社 \\
\hline 織 田 正三 & 郎 & 東邦化器工業（株） \\
\hline 浜＼cjkstart泰 & 二 & 大日本紡東京製䋐工場 \\
\hline 沢 長 & 夫 & 日本レイヨン（株） \\
\hline
\end{tabular}

會 員 異 動

[転勤・転 居]

田中 清 助鐿紡丸干工場人

中 村 诚中央纎推大垣工場一

石橋 保 大日本紡坂越工場

\begin{tabular}{|c|c|c|}
\hline 井上 & 勇 & 大同毛織稻沢工場へ \\
\hline 本 & 裕 & 浜松農高へ \\
\hline 伊能源 兵 & 衞 & 吳坊紡大町工場人 \\
\hline 橋 正 三 & 郎 & 郡是製系津山工場人 \\
\hline 野 勝 & 也 & 倉紡本社へ \\
\hline 田壽 栄 & 久 & 倉紡安城工場へ \\
\hline 藤 & 明 & 伊藤忠商事本社人 \\
\hline 久 㰾 正 & 夫 & 吳狗紡本社人 \\
\hline 井 出 三 & 省 & 大日本紡山崎工場入 \\
\hline 白 木 & 等 & 東洋レーヨン愛媛工場へ \\
\hline 西川文子 & & 布施市高井田1281 (吳旸寮) 一 \\
\hline
\end{tabular}

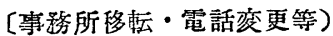

大東紡織大阪出張所は

大阪市東区今橋 2 19 (同和火炎第 2 ビル) 人移転

電話北浜(234800.3770

近江絹糸紡本店は 市內東区瓦町 305 人移檕

電話北浜(23) $726 \sim 9$

北陸織维機器汸同组合 電話番号変更

金沢(3)局4505～7

遠川織機 (株) 大阪出張所䉓話增設北浜(235720

吉円铁工所は（株）吉田鉄工所飞萑名夜更す

正䛇 表

O24号、阪本久五郎 コーンワィンターの研究

31 頁左僛 23 行の 16 自穐張力変化裝置」の後に（特許 出願中）と附加する

○24号、外國交献 コーン・ワインデングに拈ける時間 研究

48頁左钼下方の表中「糸之太さ」の項に打いて「㧧毛 糸」とあるは「紡毛糸」と訂正する。及「紡毛糸」之 二ケ所あるはいつれも「梳毛糸」と訂正する。

\title{
刊行圖書目 錄
}

豊田自動 織 機 (織機叢書第 2 集) 何原閏次 280 円 (20円)

織譏 論文集

スーパー・ハイドラフト第1集

スーパー・ハイドラフト第2集

各種化學縄維性能構造一覽表 (研究資柱No 1)

カレンターーロールにこんて

サンフォラインンク仕上につんて（研究資栏No 2)

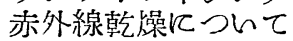

阪本久五郎

賣切礼

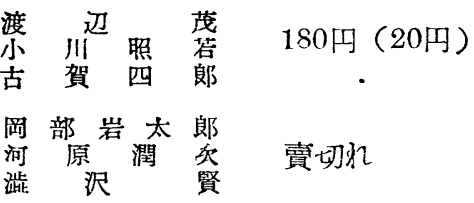

賣场规

藤 野岸 素 光 120 円 $(12$ 円 $)$

自動制微論(研究資析No 3)

阿井管 次

50 円 (6円)

織 維 機 械 學 會 誌

第3卷第9号（通突25号）

昭和 25 年 9 月 10 日刊行

定 膤 金80円

迮料 3 円
編集英発行人

印剧所

発行所

高 橋 安人

頒價(括弧內は迕林) 